Pregledni naučni rad

Primljeno: 16. 7. 2016.

UDK: 341.456

Revidirana verzija: 11. 11. 2016.

351.746 .2

Prihvaćeno: 14. 11. 2016.

doi: 10.5937/nabepo21-11401

\title{
EUROPEAN UNION'S INFORMATION EXCHANGE LEGAL FRAMEWORK - A PREREQUISITE FOR SUCCESSFUL CO-OPERATION IN FIGHTING ORGANIZED CRIME
}

\section{Nenad Radović ${ }^{1}$ \\ Zoran Đurđević ${ }^{2}$}

Academy of Criminalistic and Police Studies, Belgrade

Summary: The contemporary social conditions increasingly enable the development of transnational organized crime. Considering this fact a global response is required, or rather the development of general strategies of international character. The authors of the paper discuss certain, i.e. the most dangerous forms of organized crime which are present in Serbia as well as in the entire international community. Also, in order to make investigations and prosecutions easier, it is necessary to develop cooperation. Information exchange, as well as exchange of intelligence and evidence collecting data is a prerequisite for improving safety. Timely access to the relevant and objective information is a key element for successful detection, prevention and proving criminal offenses. Enhancing the co-operation, defining the legal framework and the establishing of technical possibilities, particularly with the handling of electronic, digital evidence, effective and timely compliance with requests for mutual legal assistance are prerequisites for success.

1 Associate Professor Nenad Radović, PhD; nenad.radovic@kpa.edu.rs

2 Associate Professor Zoran Djurdjević, PhD; zoran.djurdjevic@kpa.edu.rs 
Keywords: transnational organized crime, information, collecting data, information exchange, European information exchange framework.

\section{Introduction}

There is a large number of criminal activities which can be seen as organized crime, including drug trafficking, arms trafficking, smuggling of migrants, human trafficking, high-tech crime, etc. Detection, clarification and solving of these forms of crime is a very demanding and uncertain job for criminal police departments. Since the common trait of organized crime is that it is transnational, problems that occur are related to inadequate cooperation between countries, inability to secure appropriate evidence, unwillingness of victims to cooperate with the authorities of formal social control before and during the criminal proceedings. Supranational trait of crime demands supranational approach, supranational cooperation whose one of the most important quality indicators is the information exchange. Quality cooperation in the information exchange is the basis for threat assessment, detection and proving the acts of organized crime.

Organized crime today is not the same as it was in the period of Prohibition in the United States or in the Mario Puzo's film "The Godfather". It threatens and endangers democratic governance, processes of transition and modernization in many parts of the world, and also national and international security. Countries have become obsolete models of organization: the point is that we are trying to fight the phenomenon of the $21^{\text {st }}$ century (organized crime) using the structure, mechanisms and instruments which are still based on the concepts from the $18^{\text {th }}$ and $19^{\text {th }}$ century. ${ }^{3}$

However, in order to combat organized crime, modern police and justice systems are trying to see through the essence of this phenomenon, and try to predict its dynamics in a particular area and particularly as far as possible. A precondition for this is possession of sufficient quantities of high-quality information, including serious intelligence that occurs in two basic forms: strategic and tactical. Using thorough analysis, modern countries strive to define their areas (regions, areas, areas between other areas or other areas) which are considered particularly vulnerable to certain forms of crime, or crime in gen-

3 Williams P., Vlassis D., Combating Transnational Crime-concepts, activities and responses, Frank Cass, (2001), p.197.

[96] NBP • Žurnal za kriminalistiku i pravo 
eral, and in recent decades, particularly vulnerable to organized crime, which is definitely one of the most dangerous forms of crime. ${ }^{4}$

\section{Phenomenology of organized crime}

\subsection{Cybercrime}

Considering the fact that the use of modern IT, i.e. computers and mobile phones has greatly changed the ways of communication, it has also influenced new forms of crime to emerge such as cybercrime and enabled faster and easier communication between offenders. Nowadays we are simply flooded with e-mail, Internet forums, direct chats, etc. Internet today plays an important role in society, because on the one hand it offers a lot of profit, while on the other hand it gives the possibility to carry out various criminal activities by using sophisticated technology.

Law on organization and jurisdiction of state organs to fight cybercrime, in Article 2, introduces a new term - high-tech crime, and it is defined as the commission of criminal offenses in which computers, computer networks, computer data, as their products in material and electronic form are used either as a target or as a mean of committing a crime. ${ }^{5}$

The European Convention on Cybercrime adopted in Budapest in 2001 provides for four groups of actions: ${ }^{6}$

- Actions directed against the confidentiality, integrity and availability of computer data and systems - they consist of illegal access, interception, altering of data or unauthorized system access, use of the device (production, sale, procurement for use, distribution) of programmes, passwords;

- Computer-related forgery - in which the forgery and theft are the most typical forms of attack;

- Offences related to content - "child pornography" is the most common content appearing in this group and includes the possessing, distributing or transmitting, storage or making these materials available and accessible through a computer system, their production for distribution and processing on a computer system or on a computer-data storage medium;

4 Škulić M, Organizovani kriminalitet - pojam i krivičnoprocesni aspekti, Beograd: 2003, p. 27.

5 Official Gazette, 61/05, Law on organization and jurisdiction of state organs to fight cybercrime, in Article 2.

6 European Convention on Cybercrime, Official Gazette, No.19/2009

NBP • Journal of Criminalistics and Law [97] 
- Offenses related to infringements of copyright and related rights include reproduction and distribution of unauthorized copies of works by computer systems. ${ }^{7}$

According to the FBI report, which refers to a serious loss of money and current scams in 2010 it was stated that the damage from the common scams on the Internet amounted from $\$ 223$ (payment card frauds) and up to $\$ 3,000$ (cheque frauds) per application. ${ }^{8}$ The same year application categories were related to the following forms of crime: non-delivery of ordered goods; fraud on auction sites; fraudulent use of payment cards; frauds by abuse of trust; computer frauds; cheque frauds; "Nigerian scams"; identity theft; frauds in connection with fake financial instructions."

Zivanovic (Head of the Cyber Crime Department at the Serbian Ministry of Internal Affairs) emphasizes that one of the priorities of the Serbian Interior Ministry in the field of confronting cybercrime is protection of children and young people in terms of preventing the spread of child pornography through the Internet. He also mentioned the police action "Armageddon" in which 65 people suspected of child pornography through the Internet have been arrested since 2009, and several terabytes of pornographic material and 75 computers have been seized. ${ }^{10}$

\subsection{Smuggling of weapons and ammunition (Arms trafficking)}

According to the estimates by the United Nations Office on Drugs and Crime in 2010, criminal organizations generated an annual income between 170 and 320 million dollars in the world on the black market. ${ }^{11}$ However, according to the report of the US Council on Foreign Relations, it is estimated that the revenue from these types of criminal activities (arms trafficking) in 2012 was much higher, i.e. it amounted up to about a billion dollars. ${ }^{12}$

Unlike the legal arms trade, various forms of illegal arms are usually carried out in violation of the embargo, which is introduced by the international community to the parties involved in armed conflicts. This type of smuggling is an activity which is great social danger. The weapon is purchased in order to be resold, so that the profit could be made. The need of an individual or a

7 Urošević,V., Ivanović,., Uljanov,S, Mač u World Wide Web-u - Izazovi visokotehnološkog kriminala, Eternal mix, Beograd, 2012, p. 27.

8 Ibidem

9 Lemieux, F., Investigating Cyber Security Threats:Exploring National Security and Law Enforcement Perspectives, The George Washington University, 2011, p. 9.

10 Politika -dnevne novine, 28.10.2012.

11 https://www.unodc.org/unodc/en/frontpage/2012/July/new-unodc-campaign-highlights-transnational-organized-crime-as-an-us-870-billion-a-year-business.html 12 https://www.unodc.org/documents/data-and-analysis/Studies/Illicit_financial_flows

[98] NBP • Žurnal za kriminalistiku i pravo 
group for armaments is used by the organizers and the dealer network of resellers for making profit. The demand for these goods relates to different types of weapons (rifles, machine guns, pistols, mortars, rocket launchers, grenades, etc.) and it is directly connected to the socio-political situation in certain areas. In this sense the demand for arms is higher by separatists, for the purposes of war, personal protection, etc. ${ }^{13}$ The largest part of small arms is nowadays being produced in the developed countries, and the major manufacturers are the United Kingdom, the USA, France, Germany, Spain and Italy. Considering the fact that the developing countries promote the production of weapons, the lack of control, corruption and sponsorship by the state may have a significant effect on the increase in weapons which is being sent to the existing or emerging conflicts.

Arms trafficking is done through various channels and roads in which transport by a certain mean of transport is a particularly elaborate strategy. These organizations often have means of transport or hire them to transport goods which are accompanied by forged documents. It involves major investment and people trained for smuggling activities. Production of chemical and biological weapons of mass destruction or attempts of some countries to produce nuclear weapons represent a constant threat to the security of many countries. Also, certain criminal and terrorist organizations are trying to acquire this type of weapon.

In September 2010, the joint action of the BIA and the French security services interrupted the chain of illegal trafficking of weapons which were acquired in Serbia and Bosnia and Herzegovina, and then illegally transported to France and sold on the black market. On that occasion, an eight-member criminal group, whose members were Serbian citizens, was arrested. ${ }^{14}$

\subsection{Drug smuggling}

The representative of Interpol, Raymond Kendall said: "Drug trafficking is in the hands of organized crime." Interpol has dossiers of 250,000 serious criminals of whom 200,000 are related to drug trafficking. "In fact, transnational criminal organizations, which now control most of the drug trafficking (Colombian and Mexican drug cartels: cocaine and heroin; Chinese triad: the Golden Triangle heroin; Italian, Albanian and Turkish-Kurdish criminal groups: Golden Crescent heroin, etc.) are vital for the global drug trade because they link the agricultural sector of production which is in the hands of

13 Teofilović,N., Teofilović, T., Odnosi države i organizovanog kriminaliteta,Udrženje "Nauka i društvo", Beograd, 2006, p. 50-61.

14 http://www.rts.rs/page/stories/sr/story/135/hronika/977586/balkanska-ruta-za-svercoruzja.html 
guerrillas and tribal wars participants, with the final shipment, which is let to the city's criminal groups." 15

Illegal business with drugs (primarily heroin, cocaine and marijuana) brings huge profits to the criminal underground. Illegal "drug industry" operates through divisions on "import, wholesale and retail trade" and it is organized and coordinated by the numerous criminal organizations and not by the criminal elite. ${ }^{16} \mathrm{~A}$ number of researchers have studied the structure of the distribution system of heroin, cocaine and marijuana, from producers to the end-users, where some of them indicate that there are up to eight intermediaries between the producers and final users, and the price of drugs with each of them increases significantly in comparison to its predecessor. ${ }^{17}$

European experts have noted that the Serbian criminals have established bases in Argentina, Brazil, Venezuela and Colombia. What is typical for cocaine is that this drug largely bypasses the street market of Serbia, because of high prices. Unlike heroin, which after mixing has only three to five percent of it when it gets to the streets and costs about 15 euros per gram, the price of cocaine is around 50 to 60 euros. Drug dealers of cocaine purchase it at very low cost from 5,000 to 6,000 dollars per kilogram, and then with the help of sailors transfer it by cargo ships to large Western European ports such as Antwerp, Rotterdam and Hamburg. Upon arrival in the EU, the price of cocaine, is almost ten times higher and it can reach 50,000 euros per kilogram. ${ }^{18}$

Given the geographic position, Serbia ${ }^{19}$ is a major transit area of drugs because it connects the Eastern regions where heroin is produced and processed with large and lucrative Western European markets. Drug transit area and a well-worn heroin supply route that travels westward by land from Eastern

15 Raufer, X\& Quere,S., Le crime organisé, Paris, 2008, p.7

16 Ignjatović,Đ., Škulić, M; Organizovani kriminalitet, Pravni fakultet Univerziteta u Beogradu, 2010, p. 48

17 Dobovšek B, Organizovani kriminalitet kao perspektiva kriminalističke nauke. - U: Dani kriminalističkih nauka - mjesto i perspektive kriminalističkih nauka i kriminalističke profesije u savremenim uslovima, Zbornik radova, Sarajevo, 2001, p. 247-260.

18 Politika - dnevne novine, 19. 11. 2012.

19 According to the sources of the Ministry of Internal Affairs of Serbia, only in 2006, about 700 kilograms of heroin was seized, mostly of Afghan origin, then 13 kilograms of cocaine, 60 kilograms of hashish and 19,000 pieces of ecstasy. During the period of 20042006 about 1.4 tons of heroin were seized. Almost 90\% of this amount continues its journey to the west, and the rest of it is used for the market in Serbia. Cocaine comes mainly from South America, synthetic drugs from the Netherlands and Belgium, while marijuana is considered a "domestic product": in 2006, 2 tons of marijuana produced in Serbia were seized and the total number was 6,300 seizures of narcotics on the territory of the state. The Serbian Customs Administration also made significant seizures of a total value of more than four and a half million euros (Vecernje novosti, 14/03/2007) - Taken from the work of Marija Reljanović, 2008. The forms of organized crime, Catalogue - Fighting organized crime in Serbia, Belgrade. 
regions is called the "Balkan drug route". The shipments of drugs start their journey from Turkey (Istanbul is an important point), they enter the territory of Serbia via Bulgaria and go through Belgrade by highway, in the direction of Subotica, and then through Hungary to the West. The second branch of the "Balkan Route" goes from Greece via Macedonia and Kosovo through Serbia and Hungary to the west. According to Interpol, about $80 \%$ of the total quantity of narcotics intended for the Western market goes this way. The "Balkan route" is mostly used by the drug mafia from Iran, Lebanon, Turkey and Bulgaria. The activity of Albanian mafia is very high, but organized groups of drug dealers from Belgrade and Serbia have also been active. ${ }^{20}$

\subsection{Smuggling of migrants}

The very distinction between the concepts of trafficking and smuggling of human beings leads to the creating of specific strategies and tactics in order to suppress and prevent any of the aforementioned phenomenon, especially in the countries of destination. Seen as victims whose human rights are violated, the persons who are the subject of trade are likely to benefit from such treatment. Such measures shall not be applied to persons who are the subject of smuggling. They can expect the measures such as detention, retention, accusing and deportation. ${ }^{21}$

The primary emphasis in the overall strategy against illegal migrations and trafficking are described in the strategy document of Europol titled "Combating illegal migration and trafficking of human beings in the European Union". Intentions and actions are designed in order to "defend the borders". Measures and actions should be taken in the countries of origin and transit countries, as closely as possible to the cause of the problem. Basic activities for combating illegal migrations could be determined in the following way: the activities at the external borders, especially in the countries of origin and transit countries; measures at the external borders, border checks and border surveillance; activities within the territory of the country, monitoring the status of foreign citizens.

In spite of the restrictive immigration policies, which have been applied since the 1970s in most of the Member States, a large number of migrants continued to arrive into the European Union in search for work and asylum-seeker status, as well as a large number of illegal migrants. Using people who want to get abroad in search of better conditions of life, smuggling networks are 20 Simonović, B, Kriminalistika, Pravni fakultet u Kragujevcu - Institut za pravne i društvene nauke, Kragujevac, 2004, p. 640.

21 Banović, B; Trgovina ljudima i zaštita ljudskih prava, Nauka -Bezbednost - Policija, Vol. 8, No 1/2003, p. 81-93. 
taking control of this kind of crime across the EU. This situation implies mobility of significant resources to be used in order to combat irregular migration in a proper way. However, the EU needs a certain number of migrants to work in certain sectors and regions, since there is one element of European Union policy which is set to deal with the Union's economic and demographic needs.

Europol points out that a large number of migrants are largely brought across the Balkans to the EU by the networks of organized crime, which can be confirmed by the arrest and connections of Bulgarians and Hungarians accused of the death of 70 migrants in a truck in Austria. Also, Frontex officials, European Agency for the Management of Operational Cooperation at the External Borders, warn that the perennial earnings of smugglers can now be measured in hundreds of millions of euros, and report that it is clear that criminals have "partly changed their focus from drugs and weapons on the more profitable business-smuggling migrants".

Also, smuggling of migrants in the world is not evenly perpetrated, and most of smuggling is concentrated in a relatively small number of the developed countries, namely $75 \%$ of all international migrants live in 28 countries. There are three main countries of origin: India ( 20 million), China ( 35 million) and the Philippines (around 7 million), while on the other hand, as the most common places of migrants' destinations are the USA, the Russian Federation and Germany. If we take a look at world regions, we will see that Europe, with about 56 million migrants, has the largest migrant population in the world, followed by Asia with 50 million. According to the relevant estimates, in the world today there is between 30 and 40 million irregular migrants, which is about $15-20 \%$ of the global total "immigrant contingent". The largest number of irregular migrants are in the United States: between 11 and 12 million, while in Europe there are 8 million of them. ${ }^{22}$

Germany, Italy, France and other Western countries are faced with intense activities of organized criminal groups in the field of organizing the smuggling of the Turks, Iranians, Iraqis, Syrians and Albanians, while on the other hand, the French and the Spanish are faced with confronting the illegal entry of people from Africa and South America. Illegal migrations which are taking place across the Balkans represent a major problem for the majority of the European Union Member States. Smuggling of migrants does not only take place between Eastern and Western European countries, but there is also a relation between the Middle East and the USA. Irregular migrants are today considered as persons in need of protection considering the possibility of their vulnerability they are exposed to by organized criminal groups. The existence

22 Skupnjak - Kapić; Globalni migracijski trendovi i međunarodna iskustva u sprovođenju useljeničkih politika, Hrvatska gospodarska komora, U - Useljenička politika u funkciji razvoja hrvatskog gospodarstva, Zagreb, 2008, p. 112-125. 
of a market encourages their exploitation and the possibility of their victimization. This situation is further worsened because in the countries which they migrate to they have the limited possibilities for getting assistance, due to the lack of language knowledge and fear of the formal social control authorities.

\subsection{Trafficking in human beings}

When it comes to the acts associated with human trafficking, a victim can be any person, male, female, adult or minor, but particularly vulnerable categories are women and children. Although there is no precise profile of a potential trafficking victims, there are some basic characteristics that are often repetitive and look like constants: most often the victims are women and girls, then children, and finally men; the victims are mostly between 18 and 25 years old, although there is notable increase of young girls as victims; the victims are usually recruited from small rural villages, towns and cities in poor areas; they are mostly unemployed and poor people, mainly of only elementary education and discriminated against in their private and professional lives; they often come from families with a lot of problems and families with the history of violence; when it comes to children, the victims are often Roma or black population; victims rarely speak foreign languages and are usually motivated by a desire to improve their living conditions. ${ }^{23}$

In reality there are various forms of exploitation of women, however, the most widespread is trafficking of women for sexual exploitation. Research indicates that the average age of women from Eastern Europe is about 21 years, but among them there are minors and girls under 14 years of age. There are situations when the police want to return the woman - victim of human trafficking to her family, but it happens that they refuse to do that because of fear of traffickers' retaliation. When we talk about human traffickers (women) we should mention their relationship with the victims whose life stories are very terrifying.

These individuals are very cunning, clever, resourceful and skillfull when it comes to concealing their criminal activities. The brutality and unscrupulousness appear as the most common methods that they use. ${ }^{24}$

Transnational trafficking of women for sexual exploitation is a problem that many countries recognize, but if it is talked about only on the basis of official

23 Skakavac, Z, Krivičnopravni okviri trgovine ljudima, doktorska disertacija, Pravni fakultet Univerziteta u Kragujevcu, 2005, p. 72

24 Radovic,N; Women and children trafficking for sexual exploitation, published in NBP-Journal for Criminology and Law, The Academy for Criminalistic and Police Studies, Belgrade, 2007, p. 95-112. 
statistical data, there is little to be said. ${ }^{25}$ In fact, considering the fact that it is a very covert activity, it would be illusory to expect that adequate statistics data about the extent and dynamics of these phenomena are available. In a great deal of countries the most common source of information on this issue are official police statistics, but the police has only one part of data because they generally identify victims of trafficking who know very little about the overall organization of criminal groups.

The International Labour Organization (ILO) estimates that 8.4 million children are included in trafficking and in that respect they are forced to various forms of labour, participation in armed conflicts, forced into prostitution, pornography and other illegal activities and there are also around 30,000 child soldiers involved in over 30 conflict areas around the world, and some of them are under the age of $10 .{ }^{26}$

Although trafficking of women and children is considered to be the most frequent one when we talk about human trafficking, yet there are some cases in reality where adult males become victims of human trafficking.

Some countries are well known in the world as countries where an extensive network of trafficking in human organs exists. This is primarily in India, Thailand, Moldova, Turkey, Romania, Albania and certain Latin-American countries, Cambodia, Vietnam, as well as some countries of Western Europe and the USA.

The results of the research of trafficking of men in Serbia have confirmed details of some earlier research that showed the increase in the number of identified male victims as well as the area of origin, not only women, but also male victims. The number of 407 victims of men trafficking for the period from 2003 to 2007, identified by our research, exceeds the number of victims who are in the records of the police and the Agency for Coordination of Protection of Victims of Human Trafficking. ${ }^{27}$

The case that had taken place in Kosovo and Metohija more than ten years ago attracted great deal of attention in Serbia. The War Crimes Court in Belgrade, on 26 March 2008, initiated pre-trial proceedings concerning the alleged sale of organs of Kosovo Serbs during and after the bombing of the Federal Republic of Yugoslavia. The War Crimes Prosecution announced earlier that they formed the subject relating the sale of organs of Kosovo's Serbs.

25 Kovčo, I; Organizovani kriminalitet: pedofilija i prostitucija. Hrvatski ljetopis za kazneno pravo i praksu, Zagreb, No 2, 1998, p. 642-659.

26 http://www.ilo.org/global/about-the-ilo/newsroom/news/WCMS_007784/lang--en/ index.htm

27 Nikolić - Ristanović, et al; Trgovina muškarcima u Srbiji, Viktimološko društvo Srbije, Beograd, 2009, p. 255. 
The National Assembly of the Republic of Serbia, on 20 July 2005, formed an Inquiry committee to determine the truth about the missing/stolen newborn children. Our country is known for unexplained cases of human babies trafficking, which occurred in the period from 1970 to 1990. It is believed that according to some estimates there are up to 30,000 parents who suspect that their babies were abducted after their birth and there are 3,000 families in Serbia who search for their children.

Efficient combating and supressing of human trafficking includes the measures which will act to reduce supply, i. e. the demand which is the main cause of human trafficking. ${ }^{28}$

\section{Legal framework and standards of European Union for information exchange}

The European Parliament, the Council of the European Union, the Council of Europe and the European Commission taking into account the social dangers of organized crime and the need for harmonization of the unique response and coordination of joint efforts of all Member States have passed a series of legal documents, policies, strategies and action plans which should help confronting serious and organized crime. ${ }^{29}$

In order to make investigations easier, simplify the procedures and prosecutions it is necessary to develop cooperation. Information exchange, intelligence and evidence data exchange is a prerequisite for improving safety. Timely access to relevant and objective information is a key element for successful detection, prevention and proving of criminal offenses. Enhancing cooperation, defining legal frameworks and creating environment with technical possibilities, particularly with the handling of electronic, digital evidence, effective and timely compliance with requests for mutual legal assistance are prerequisites for success.

The Council of the European Union adopted the first Action Plan to combat organized crime in Amsterdam on 16 and 17 June 1997..$^{30}$ The Action Plan

28 Golubovic,S, Golubovic,N; Application of rational choice theory in the analysis of human trafficking, published in NBP-Journal for Criminology and Law, The Academy for Criminalistic and Police Studies, Belgrade,2011, p. 94-107.

29 Djurdjevic Z., et al, Methods of threat assessment of serious and organized crime, published in: Combating contemporary forms of crime-analysis of the situation, European standards and measures for improvement, The Academy for Criminalistic and Police Studies \& "Hanns Seidel"Foundation, Belgrade, 2015, p. 309-324.

30 Council ofthe European Union, Action plan to combat organized crime, 97/C 251/01, OJ C 251, 15.8.1997, p. 1, http:// eur-lex.europa.eu > ... > EU law and publications > EUR-Lex, $\operatorname{aspx}(18.8 .2016)$. 
was drawn by a High Level Group of experts at the request of the Heads of State and Governments and the plan was defined at a meeting in Dublin in December 1996. The Action plan represents universal approach to organized crime with a special focus on prevention. What was emphasized in it was the need to invest additional efforts in harmonizing laws and standards of practical cooperation between law enforcement agencies, the judiciary and the police. Recommendations 6,7 and 8 are related to the collection and exchange of information. The key role in the coordination of activities in combating organized crime was given to Europol (Recommendations 10). ${ }^{31}$

During the short period of application of the Action Plan certain progress has been achieved in development and implementation of measures for prevention and control of organized crime. An example of progress is also a quote from the Official Journal of the European Communities: "European Judicial Network is equipped with a telecommunications network and Falcone programme. The Union has made its voice heard in the negotiations at the UN on the draft Convention on Transnational Organised Crime and in the Council of Europe on the draft Cyber-Crime Convention." ${ }^{32}$

In December 1998 in Vienna, The Council of Europe called for the strengthening of EU action against organized crime in accordance with the changes that had occurred and in the light of the new possibilities opened by the Amsterdam Treaty, the review and evaluation of the Amsterdam Treaty and to consider the possibility of its continuation (see: X - Justice and Home Affairs, conclusion 89). ${ }^{33}$

On 15 and 16 October 1999 at its meeting held in Tampere the Council of Europe stressed the need for joint mobilization of police and judicial resources with the aim of creating a platform that would guarantee that there is no hiding place (shelters) for criminals or the proceeds of crime within the Union (Presidency Conclusion No 6.). It was stressed there was the need to adopt a clear and coherent EU strategy to counter organized crime. Thus, in order to achieve a higher level of harmonization of states' policies, the Council of the European Union in 2000 drew up: the Prevention and Control of Organised Crime: A European Union Strategy for the Beginning of the New Millenni$\mathrm{um},{ }^{34}$ the Convention on Mutual Assistance in Criminal Matters between the

31 Ibidem, Part II - Political guidelines.

32 Quotefrom Council ofthe European Union, The Prevention and Control of Organised Crime: A European Union Strategy for the Beginning of the new Millennium, Official Journal of the European Communities, 2000/C 124/01, http://eur-lex.europa.eu > ... > EU law and publications > EUR-Lex, aspx (18.8.2016)

33 European Council,Presidency conclusions, Vienna, 11 and 12 December 1998, http:// www.europarl.europa.eu/summits/wie1, aspx (24/11/2015)

34 Council of the European Union, The Prevention and Control of Organised Crime: A European Union Strategy for the Beginning of the new Millennium, Opus citatum. 
Member States of the European Union (adopted on 29 May 2000 in accordance with Article 34 of the Treaty on European Union) ${ }^{35}$ and the Protocol to the Convention on Mutual Assistance in Criminal Matters between the Member States of the European Union. ${ }^{36}$

Millennium strategy defines the political guidelines and 39 recommendations for prevention and control of organized crime: ${ }^{37}$ our years after millennium strategy, in 2004 the European Council adopted the Hague Programme. The Hague Programme introduced the principle of availability, according to which Member States which have the information necessary for the application of the laws in other countries are to make them available. The European Council stressed that when implementing the principle of availability one must respect the following conditions: the subject of exchange may only be the information which is necessary when legal tasks are to be performed; integrity of data to be exchanged must be guaranteed; it is necessary to protect sources of information and ensure confidentiality of the data at all stages of the exchange, and subsequently; define common standards for access to the data; supervision of respect for data protection, and appropriate control and guarantee prior to and after the exchange must be ensured; and there must be protection against the abuse of data and have the right to seek correction of incorrect data. ${ }^{38}$

In accordance with the conclusions of the Hague Programme in $2006 \mathrm{Eu}-$ ropol instead of giving standard report on the crime situation gave the assessment of danger for the European Union from organized crime (OCTA-European Union's Organised Crime Threat Assessment). ${ }^{39}$

35 Council of the European Union, Convention on Mutual Assistance in Criminal Matters between the Member States of the European Union, Official Journal of the European Communities, 2000/C 197/01, http:// /www.europol.europa.eu/.../caonmla-2000-05-29-en.pd, aspx (19.8.2016).

36 Council of the European Union, Protocol to the Convention on Mutual Assistance in Criminal Matters between the Member States of the European Union, Official Journal of the European Communities, 2001/C 326/01, http://eur-lex.europa.eu > ... > EU law and publications > EUR-Lex, aspx (19.8.2016).

37Council of the European Union, The Prevention and Control of Organised Crime: A European Union Strategy for the Beginning of the new Millennium, Opus citatum.

38 Council of the European Union, The Hague Programme: strengthening freedom, security and justice in theEuropean Union, Official Journal of the European Communities, 13 December 2004, 2005/C 53/01, http://eur-lex.europa.eu > ... > EU law and publications > EUR-Lex, aspx (19.8.2016).

39 OCTA document was written during 2006, 2007, 2008, 2009 and 2011. In the threat assessment from 2007 the following priorities were stressed: preventing creation and distribution of organised crime groups aspiring to expand their influence and commit offenses on a wider international level; preventing infiltration of organised criminal groups in society (in public administration and economy), especially misuse of legitimate business-related structures (especially in the transport sector); preventing abuse of technology. 
In order to ensure effective and rapid exchange of information made two separate legal acts were drawn up for the exchange of information: Swedish Framework Decision and Prüm Decisions.

Swedish Framework Decision of 18 December 2006, simplified the exchange of information and intelligence between the Member States of the European Union. Framework Decision regulates: time limits for provision of information and intelligence; requests for information and intelligence; communication channels and language; spontaneous exchange of information and intelligence; data protection; confidentiality; reasons to withhold information or intelligence (TITLE II - Exchange of Information and Intelligence, Article $4-10){ }^{40}$

Most Member States adopted the Swedish Framework Decision. However, it has not still been fully implemented, so that all its potentials have not been exploited yet. Instead of using the Decision as a legal remedy, it is mainly associated with the forms that are presented in it for data exchange. Deadlines are considered useful and are respected in most cases. However, the mandatory channelling of requests through a Single Point of Contact (SPOC) in some Member States violates the principle of equivalent access, because the time between the source and the end-user of information is prolonged.

Great importance for improving the exchange of information was also Prüm Decisions. ${ }^{41}$ In the preamble to the Decision it is indicated that the original Prüm was signed in 2005 between Austria, Belgium, France, Germany, Luxembourg, the Netherlands and Spain, in pursuance of the stepping up of cross-border cooperation, particularly to combat terrorism, cross-border crime and illegal migration. ${ }^{42}$ The decision sets out: Common provisions for data exchange (Technical specifications; Communications network; Availability of automated data exchange; Reference numbers for DNA data and dactyloscopic data; ); DNA data (Principles of DNA data exchange; Rules for requests and answers in connection with DNA Data; Transmission procedure for automated search of reference DNA profiles; Transmission procedure for automated comparison of unidentified DNA profiles); Dactyloscopic data (Principles for the exchange of dactyloscopic data; Search capacities for dactyloscopic data; Rules for requests and answers in connection with dactyloscopic data); Vehi-

40 Council of the European Union, Council Framework Decision 2006/960/JHA,Official Journal of the European Union, L 386/89, http://www.statewatch.org/.../eu-council-swed-init-implementation-1, aspx (10.6.2016).

41 Council of the European Union,Council Decision 2008/616/JHAof 23 June 2008on the implementation of Decision 2008/615/JHA on the stepping up of cross-border cooperation,particularly in combating terrorism and cross-border crime, http://eur-lex.europa.eu > ... > EU law and publications > EUR-Lex,aspx (21.11.2015).

42 Ibdem. 
cle registration data (Principles of automated searching of vehicle registration data; Costs); Police cooperation (Joint patrols and other joint operations). ${ }^{43}$

Despite these decisions (Swedish Framework Decision and Prüm Decisions) there still existed many problems in the exchange of information, mostly as a result of differences in national legal and technical systems. This was precisely one of the reasons why the Council of the European Union on 30 November 2009 decided to adopt the draft conclusions on "European Union Information Management Strategy" (EU IMS). ${ }^{44}$ The Strategy aims were to support, simplify and facilitate the exchange of information relevant to the internal security of the EU. It was especially stressed that there was the need for the development of information technology which will support the collection, storage, processing, analysis and exchange of information. The goal was to eliminate defects, especially problems of uncoordinated approach and incoherent information systems and instruments, which are often resulting in the delay in the exchange of information and therefore the problems in the process of proving. The decision on exchange of information too often depended on the division of responsibilities between agencies for applying laws which differed from country to country, leading to unnecessary complications. The strategy envisaged strong mechanisms for the protection of data. However, besides the mechanisms of protection in order to use available information fund of agencies, the state needs to work on strengthening the trust between states, both at the national and at the level of the EU.

During the Belgian presidency of the EU in 2009 "Project Harmony" was launched, the integration of EU instruments, including the OCTA, to a higher more consistent and efficient approach, which includes the adoption of a new policy cycle of fighting serious and transnational crime for the period between 2013 and 2017. The Council, based on threat assessment of organized crime in 2009, revised and changed conclusions on the EU priorities for the fight against organized crime. Operating under the new cycle in future concrete operational plans were presented by SOCTA (Serious and Organised Crime Threat Assessment). ${ }^{45}$ In this transitional period (2010-2013), before the start of the 2013-2017 cycle, the initial estimate for the choice of priorities 2011 OCTA was written (Organised Crime Threat Assessment). ${ }^{46}$

43 Ibdem, Article 3 - 17.

44 Council of the European Union, Draft Council Conclusions on an Information Managem ent Strategy for EU Internal security, 16637/09, Brussels, 25 November 2009.

45 Council conclusions on the creation and implementation of a EU policy cycle for organised and serious international crime, Council of the EU, Brussels, 8 and 9 November 2010.

46 The Republic of Serbia, the Ministry of Interior in accordance with the obligations defined in chapter 24- Justice, freedom and security, to join the EU, has drawn up the assessment of threats from heavy and organized crime. 
A step further was made by adopting the Stockholm Programme ${ }^{47}$ which designated Europol as the focal point for the exchange of information between law enforcement authorities of the Member States. The subject of discussion was not only "business driven development, a strong data protection regime, interoperability of IT systems and a rationalization of tools as well as overall coordination, convergence and coherence" ${ }^{\prime 48}$ but also the ways how operational police cooperation could be stepped up, e.g. as regards incompatibility of communication systems and other equipment and how it could be ensured that Europol receives information safely. In addition, the program emphasizes the need to adopt a decision on the modalities of cooperation, including the exchange of information between the EU agencies.

For the implementation of the Stockholm Programme an action plan with specific goals was adopted, with objectives and periods for their implementation. In accordance with the Action plan on 25 and 26 March in 2010 Internal Security Strategy of the EU was adopted, and with it European model of security was improved. ${ }^{49}$ The Strategy stressed the need to improve the existing mechanisms for the exchange and management of information, to develop a safe and clearly structured European model for the exchange of information (European Information Exchange Model). Exchange of information on the basis of mutual trust and the principle of availability are defined as the foundations of internal security policy. For effective behaviour of law enforcement it is necessary to create the possibility for timely access to as many data as possible: data about perpetrators, victims, modus operandi, vehicles and other relevant data that the EU member states and their national agencies have in their databases can be used for fighting crime. On the other hand, the model must ensure that the rights to privacy and protection of personal data must be respected..$^{50}$

On 7 December 2012 the European Parliament committee adopted a Communication "Strengthening law enforcement cooperation in the EU: the European Information Exchange Model (EIXM)". ${ }^{51}$ On the same day the Com-

47 Council of the European Union, The Stockholm Programme - an open and secure Europe serving and protecting citizens, Official Journal of the European Union, 2010/C 115/01. 48 Ibidem.

49 In December 2003, the European Union adopted the European Security Strategy, which was focused on the external aspects of security. European security model is completed by the 25 and 26 March 2010 by the adoption of the Internal Security Strategy for the European Union: "Towards a European Security Model", Luxembourg, Publications Office of the European Union, 2010, p. 8-9.

50 General Secretariat of the European Council, Internal security strategy for the European Union - Towards a European security model, Publications Office of the European Union, Luxembourg, 2010.

51 Commission to the European Parliament, Strengthening law enforcement cooperation in the EU: the European Information Exchange Model (EIXM), COM(2012) 735 final. 
mission adopted a report on the implementation of the Council Decisions on the exchange of information. The report stated that they did not need any new legal instruments for information exchange. The focus of the study was on the implementation of the Council Framework Decision ("Swedish Framework Decision") and Council Decisions 2008/615/JHA and 2008/616/JHA ("Prüm Decisions") on information exchange in practice regarding the organization of the Single Point of Contact (SPOC), on communication channels, the use of the Universal Message Format (UMF), and finally horizontal challenges such as training measures.

In order to further improve the model of information exchange, the Council of the European Union in 2014 adopted a "Draft Council Conclusions on an updated Information Management Strategy", which set the Information Management Strategy as a comprehensive vision of development. ${ }^{52}$ In the analysis of implementation of the Strategy the Council concluded that a larger involvement of all participants at both national and EU level is needed. ${ }^{53}$

One of the obstacles to the exchange of data within the EU are the rules for entering data in the Europol Information System (EIS), a limited number of users and the fact that EIS information is not readily available to a greater extent in the operational police work.

For the existing and future extensions of information exchange, the Universal Messaging Format (UMF, implemented and SIENA ${ }^{54}$ and which can be used for Prüm and SFD) is seen as essential, in particular for instruments where other standards still do not exist. The implementation of the UMF II is making rather slow progress, mainly due to budgetary issues but also due to the short time that has elapsed since the standard was launched. There is however a quite high interest among Member States to proceed with implementing it and also to follow the creation of the UMF III, i.e. the next version of the $\mathrm{UMF}$, extending its functions. ${ }^{55}$

Of course, we should also mention the European Union Satellite Centre - EU SATCEN which is functioning as a European autonomous capability providing products and services resulting from exploitation of relevant space assets and collateral data, including satellite and aerial imagery, and it is essential for strengthening early warning and crisis monitoring functions within the context of the common foreign and security policy and, in particular, of

52 Council of the European Union, Draft Council Conclusions on an updated Information Management Strategy (IMS) for EU internal security, 15701/1/14, Brussels, 24 November 2014.

53 Ibidem.

54 Secure Information Exchange Network Application-SIENA.

55 European Commission,Study on the implementation of European Information Exchange Model (EIXM) for strengthening law enforcement cooperation -Final Report, Belgium, Berkenlaan 8C -1831 Diegem,26 January 2015, p. 6. 
the common security and defence policy, including organized crime. Lately the center has been extremely important in monitoring migrant crisis together with Frontex. By 30 September of each year, the Director establishes a draft annual work programme and submits it to the Board for approval. ${ }^{56}$

\section{Conclusion}

The consequence of the global development of the society is a growing trend of transnational crime. Offenders and perpetrators are increasingly using modern technical achievements, free movement of goods, capital, services and people; they use the differences in legal systems and the lack of efficient cooperation between the countries for the successful committing of crimes; they expand borders of their criminal activities and avoid criminal liability. After a series of terrorist attacks in Europe, especially this year, and the migrant crisis, as well as the increase in cybercrimes and organized crime, what has been considered and discussed is changing the approach in combating crime. The global nature of crime requires an approach which goes beyond the borders of 'national' if we want to fight it. There are many indicators which reveal this fact. For example, organized crime groups, whose members are the citizens of the Republic of Serbia, smuggle cocaine from South America to the fullest extent and sell it in the market of Western Europe. On the other hand, the synthetic drugs market is becoming bigger in Serbia, and it has to be mentioned that because of the risk of detection, they are being produced here and laboratories for their production are being imported from Western Europe.

In order to define strategic directions of cooperation on the realistic and objective grounds, it is necessary to create and grasp a real picture of organized crime, and design the neccessary appropriate models for collecting, processing, classifying, analysing, storing and exchange of information.

Similarly to the mentioned transnational characteristic of organized crime besides national estimates, we must have regional ones, and in the next step also estimates in Europe and the world. When it comes to assessment of serious and organized crime threat within the borders of Europe, each member state does the assessment for itself on the basis of data submitted by Member States, Europol for the entire area of the European Union. We are pleased to say that the Ministry of the Interior, at the end of 2015, in accordance with the obligations from the Action Plan for Chapter 24 did the assessment of serious and organized crime threats in the Republic of Serbia, together with Montene-

56 Ibidem, Article 9.

[112] NBP • Žurnal za kriminalistiku i pravo 
gro and Macedonia in the first half of 2016 and also the regional serious and organized crime threat assessment.

Cooperation is the basis for combating crime in effective way. Current models of cooperation, including an information exchange, require further improvement, a more precise legal framework, standardization of work and the improvement of technical capacity.

A prerequisite for the cooperation is to create a legal framework for cooperation (bilateral, multilateral agreements) and to harmonize laws relating to the subject of cooperation. If we talk about harmonization of law, we have to consider two directions of this process. First, the harmonization of substantive and procedural criminal law in order to create a common legal basis of conduct is there to show criminal offences and the way they can be effectively detected and proved. Secondly, it is necessary to identify the areas with inadequate or various or different legal regulations which can be used for committing criminal offenses by perpetrators (for example, lately it has been drug market). Third, it is necessary to legaly define the forms and standards in cooperation. Namely, it is necessary to design legal framework which would enable to form common investigation teams with larger number of states.

The next, but not less important task, is to improve the institutional and technical capacities for the implementation of law, institutional and operational cooperation. The exchange of information is the basis of good cooperation. Only those relevant, truthful, accurate and timely information can ensure the efficient implementation of proactive and reactive investigations. In order to achieve this it is necessary to create a generally accepted model of information exchange, and this will ensure data protection, on the one hand and on the other hand, this will make them available for those who need it most. This includes the standardization of work at national and supranational level, and this includes getting equipment and harmonization of systems for data exchange. Unfortunately, when it comes to the Republic of Serbia, what indicates how big amount of work still has to be done is the fact that the police, prosecution and courts keep records on crime in different ways, which is the basis for the analysis, evaluation and strategic work guidance.

Another, also big task is to improve and implement the standards of information work. One of the problems is also delay in issuing certificates for information access of different level of secrecy. At the moment, a certificate is issued if a person requires it and not on the basis of a job requirement or the need to use such information which is precisely defined. This problem, and also the standards of data storage can quickly become an obstacle for information exchange. We need to eliminate the mentioned problems in order to prepare for possible access to the databases of Europol and the European Union satellite centre (EU satcen). 
Cooperation is inevitable, it is no longer subject to analysis. What we must bear in mind at all times is that cooperation, and the level of efficiency in the protection of fundamental rights and freedoms depend on the institutional capacity to implement the law. In order to achieve a comprehensive, objective, realistic approach which is based on the results and in order to reduce the number of offenses and achieve higher level of protection of fundamental rights and freedoms, it is necessary to build institutions whose main characteristics would be independence, effectiveness, responsibility and expertise. To put this in a different way: the institutions must consist of people with high personal and professional integrity.

\section{References}

1. Banović, B; Trgovina ljudima i zaštita ljudskih prava, Nauka -Bezbednost Policija, Vol. 8, No 1/2003.

2. Council of the European Union, Action plan to combat organized crime, 97/C 251/01, OJ C 251, 15.8.1997.

3. Council of the European Union, The Prevention and Control of Organised Crime: A European Union Strategy for the Beginning of the new Millennium, Official Journal of the European Communities, 2000/C 124/01.

4. Council of the European Union, Convention onMutual Assistance in Criminal Matters between the Member States of the European Union,Official Journal of the European Communities, 2000/C 197/01.

5. Council of the European Union, The Hague Programme: strengthening freedom, security and justice in the European Union, Official Journal of the European Communities, 13 December 2004, 2005/C 53/01.

6. Council ofthe European Union, Draft Council Conclusions on an Information Management Strategy for EUinternal security, 16637/09, Brussels, 25 November 2009.

7. Council of the EU, Council conclusions on the creation and implementation of a EU policy cycle for organised and serious international crime, Brussels, 8 and 9 November 2010.

8. Council of the European Union, The Stockholm Programme - an open and secure europe serving and protecting citizens, Official Journal of the European Union, 2010/C 115/01.

9. Council of the European Union, Draft Council Conclusions on an updated Information Management Strategy (IMS) for EU internal security, 15701/1/14, Brussels, 24 November 2014. 
10. Commission to the European Parliament, Strengthening law enforcement cooperation in the EU: the European Information Exchange Model (EIXM), $\operatorname{COM}(2012) 735$ final.

11. General Secretariat of the European Council, Internal security strategy for the European Union - Towards a European security model, Publications Office of the European Union, Luxembourg, 2010.

12. Dobovšek B (2001), Organizovani kriminalitet kao perspektiva kriminalističke nauke. - U: Dani kriminalističkih nauka - mjesto i perspektive kriminalističkih nauka i kriminalističke profesije u savremenim uslovima, Zbornik radova, Sarajevo.

13. Golubovic, S., Golubovic, N; application of rational choice theory in the analysis of human trafficking, published in NBP-Journal for Criminology and Law, The Academy for Criminalistic and Police Studies, Belgrade, 2011.

14. Djurdjevic Z.,Jokanović, S., Sovtić, S., Methods of threat assessment of serious and organized crime, published in : Combating contemporary forms of crime-analysis of the situation, European standards and measures for improvement, The Academy for Criminalistic and Police Studies \& "HannsSeidel"Foundation, Belgrade, 2015.

15. European Council, Presidency conclusions, Vienna, 11 and 12 December 1998, http://www.europarl.europa.eu/summits/wie1, aspx (24.11.2015).

16. European Commission, Study on the implementation of European Information Exchange Model (EIXM) for strengthening law enforcement cooperation -Final Report, Belgium, Berkenlaan 8C - 1831 Diegem, 26 January 2015.

17. Ignjatović, Đ., Škulić, M; Organizovani kriminalitet, Pravni fakultet Univerziteta u Beogradu, 2010.

18. Kovčo, I; Organizovani kriminalitet: pedofilija i prostitucija. Hrvatski ljetopis za kazneno pravo i praksu, br. 2/1998, Zagreb.

19. Lemieux, F., Investigating Cyber Security Threats: Exploring National Security and Law Enforcement Perspectives, the George Washington University, 2011.

20. Nikolić - Ristanović, et al; Trgovina muškarcima u Srbiji, Viktimološko društvo Srbije, Beograd, 2009.

21. Radovic, N; Women and children trafficking for sexual exploitation, published in NBP-Journal for Criminology and Law, The Academy for Criminalistic and Police Studies, Belgrade, 2007.

22. Raufer, X \& Quere, S., Le crime organisé, Paris, 2008. 
23. Simonović, B; Kriminalistika, Pravni fakultet u Kragujevcu - Institut za pravne i društvene nauke, Kragujevac, 2004.

24. Skupnjak - Kapić; Globalni migracijski trendovi i međunarodna iskustva u sprovođenju useljeničkih politika, Hrvatska gospodarska komora, U - Useljenička politika u funkciji razvoja hrvatskog gospodarstva, Zagreb, 2008.

25. Skakavac, Z; Krivičnopravni okviri trgovine ljudima, doktorska disertacija, Pravni fakultet Univerziteta u Kragujevcu, 2005.

26. Teofilović, N., Teofilović, T, Odnosi države i organizovanog kriminaliteta, Udruženje "Nauka i društvo", Beograd, 2006.

27. The Council of the European Union, Council Decision 2014/401/CFSP of 26 June 2014 on the European Union Satellite Centre and repealing Joint Action 2001/555/CFSP on the establishment of a European Union Satellite Centre, Official Journal of the European Union L 188/73, http/: http://eurlex.europa.eu/oj/direct-access.html.

28. Urošević,V., Ivanović,., Uljanov,S; Mač u World Wide Web-u - Izazovi visokotehnološkog kriminala, Eternal mix, Beograd, 2012.

29. Škulić M; Organizovani kriminalitet - pojam i krivičnoprocesni aspekti. Beograd: Dosije, 2003.

30. Williams P., Vlassis D., Combating transnational Crime- concepts, activities and responses, Frank Cass, 2001.

31. http://www.rts.rs/page/stories/sr/story/135/hronika/977586/balkanska-ruta-za-sverc-oruzja.html

32. http://www.ilo.org/global/about-the-ilo/newsroom/news/ WCMS_007784/lang--en/index.htm

33. https://www.unodc.org/unodc/en/frontpage/2012/July/new-unodc-campaign-highlights-transnational-organized-crime-as-an-us-870-billion-ayear-business.html

34. https://www.unodc.org/documents/data-and-analysis/Studies/Illicit_financial_flows 


\title{
RAZMENA INFORMACIJA - PREDUSLOV USPEŠNE SARADNJE U SUPROTSTAVLJANJU ORGANIZOVANOM KRIMINALU
}

\author{
Nenad Radović \\ Zoran Đurđević
}

Kriminalističko-policijska akademija, Beograd

Sažetak: Savremeni društveni uslovi sve više omogućavaju razvoj transnacionalnog organizovanog kriminala. $\mathrm{S}$ tim u vezi, potreban je globalni odgovor ili, bolje rečeno, razvoj generalnih strategija međunarodnog karaktera. Autori se u radu osvrću na pojedine, najopasnije oblike organizovanog kriminala koji su prisutni kako u Srbiji tako i u čitavoj međunarodnoj zajednici. Takođe, da bi se olakšale istrage i krivična gonjenja, neophodno je razvijati saradnju. Razmena informacija, obaveštajnih i dokaznih podataka preduslov je za poboljšanje bezbednosti. Blagovremen pristup relevantim i objektivnim informacijama ključni je element za uspešno otkrivanje, sprečavanje i dokazivanje krivičnih dela. Unapređenje saradnje, definisanje pravnih okvira i uspostavljanje tehničkih mogućnosti, naročito za rukovanje elektronskim, digitalnim dokazima, i efikasno i blagovremeno postupanje u skladu sa zahtevima za uzajamnu pravnu pomoć - preduslovi su za uspeh. 